UDK 364-646.2(4-67EU:497.7)

340.114(4-67EU:497.7)

Original scientific article

\title{
SOLIDARITY CHECK IN TIMES OF COVID-19. ANALYSIS OF THE EU APPROACH TOWARDS ITS CLOSEST NEIGHBOURS WITH A SPECIAL FOCUS ON MONTENEGRO
}

\author{
Stefan Đurić, PhD Candidate \\ Faculty of Law, University of Belgrade \\ Bulevar kralja Aleksandra 67, Belgrade 11000 \\ sdjuricfpe@gmail.com \\ Bojana Lalatović, PhD Candidate \\ Faculty of Law, University of Belgrade \\ Bulevar kralja Aleksandra 67, Belgrade 11000 \\ bojana.lalatovic@rycowb.org
}

\begin{abstract}
Solidarity as one of the cornerstone values of the European Union has been once again seated on the red chair and intensively discussed within the European Union and broader. After the economic recession and migrant crisis that marked the last two decades, the outbreak of the COVID-19 pandemic has once again harshly tested the fundamental objectives and values of the European Union and the responsiveness and effectiveness of its governance system on many fronts. In April, 2020 several EU Member States were among the worst affected countries worldwide and this situation soon became similar in their closest neighbourhood. It put a huge pressure on the EU to act faster, while at the same time placing this sui generis community to the test that led to revealing its strengths and weaknesses. As it happened in the previous crises, the Union launched policies and various programmes that were meant to lessen the burden of the Member States and aspiring countries caused by the crises. The objectives of the mentioned soft law instruments that the EU adopted during the COVID-19 crisis has been not only to show that EU law is equipped to react to health and economic crises rapidly but to deliver its support in terms of solidarity to its Member States and its closest neighbours facing the unprecedented health and economic crisis.
\end{abstract}

This article will explore the value and implication of the solidarity principle in times of Covid-19 in its various manifestations. A special focus will be on the financial and material aspects of the EU instruments created to combat the negative consequences of the pandemic and their further impact on shaping the solidarity principle within the EU system. While examin- 
ing the character and types of these mechanisms a special focus will be placed on those available to Western Balkan countries, whereas Montenegro as the "fast runner" in the EU integration process will be taken as a case study for the purpose of more detailed analyses.

One of the major conclusions of the paper will be that although the speed of the EU reactions due to highly complex structure of decision making was not always satisfying for all the actors concerned, the EU once again has shown that it is reliable and that it treats the Western Balkan countries as privileged partners all for the sake of ending pandemic and launching the socio-economic recovery of the Western Balkans.

Analytical and comparative methods will be dominantly relied upon throughout the paper. This will allow the authors to draw the main conclusions of the paper and assess the degree of solidarity as well as the effectiveness of the existing EU instruments that are available to Montenegro and aimed at diminishing negative consequences of the crisis.

Keywords: COVID-19; Solidarity; European Union, Western Balkans, Montenegro

\section{INTRODUCTION}

This article will analyse the solidarity principle that lies at the very heart of the project of the European Union, being one of the cornerstone values upon which this supranational entity is based. The need for a closer insight into the topic stems from the increasing reference to this principle and its ever-growing relevance in times of pandemic. Therefore, relying on conceptual analysis the authors will draw conclusions about both legal and political aspects of this principle. Moreover, they will analyse the concept of solidarity, as well as its interconnectedness with the phenomenon of globalization and the Covid-19 pandemic, leading them to the conclusion that the European Union will have to improve solidarity mechanisms in order to be able to adequately and efficiently respond to all the challenges that lie ahead. In light of the pandemic, these challenges are primarily related to resolving the health crisis, as well as to tackling its pervasive social and economic consequences. The authors will also critically examine the concept of solidarity in times of crisis, especially the format and speed of the reaction, putting a special focus on the reforms that were introduced in order to allow the EU as a supranational entity with limited competencies in the field of health, to act in a satisfactory manner and bring tangible results also in its closest neighbourhood.

The analysis of the principle of solidarity has its theoretical and practical relevance. From a theoretical point of view, there are many conflicting observations about its nature. One group of theorists ascribe to the principle of solidarity only political nature, while the other group holds that it presents a legal principle. In other words, while the first group claims that the principle of solidarity has only an abstract or political relevance, the second one refers to it as a legal obligation. Anyhow, the answer to this topic has not yet crystallized in theory, so neither this 
paper seeks to provide an answer to the above question, but it rather seeks to provide a modest contribution towards enlightening the importance of this principle by relying upon both theories. In other words, it will point out the practical reflections of the principle of solidarity during the pandemic and based on this argue in favour of the importance of such a concept.

Looking from the short term perspective the principle of solidarity might seem as not that profitable. From the long term perspective and taking into account the benefit of a peaceful and cooperative continent, we can conclude that perseverance of the concept of solidarity significantly overrides all the expenses the member states have incurred during the pandemic or will incur in future crises the EU might face. The paper will point out the available assistance mechanisms, their development through a short historical overview, and the rationale behind them - to the extent that is necessary for this work, given its scope and wide range of available mechanisms the EU offers. One of the authors' goals is also to recontextualize European solidarity and to examine the potential of the emergence of genuine measures to promote solidarity which are the "ones that go beyond the mere coordination of 'solidarity' among different national systems." This goal could be achieved through a more detailed analysis of the current (procurement) procedures and available mechanisms that have the potential of becoming a genuine EU led "solidarity in action" means and that can generate more coordinated and effective future EU responses to crises.

After that, based on the available information, we will show the assistance provided to the EU closest neighbourhood, during the pandemic, with a special focus on Montenegro. This assistance presents a strong reflection of the genuine devotion of the EU to the Western Balkans. Since the signing of the Accession and Stabilization Agreement, the European Union besides setting conditions for democratization and strengthening the rule of law, human rights, etc. has also been generously assisting the region and Montenegro`s development through providing various pre-accession funds. Certainly, among the key aspects of this assistance is the financial and administrative support, with the aim to help candidate states to achieve economic growth and approximation to European standards. During the pandemic, the European Union once again proved to be a reliable partner for the Western Balkans. Based on the information obtained from the European Union Delegation in Montenegro, European External Action service, and other available sources, the paper will present the assistance provided by the EU to Montenegro

Di Napoli, E.; Russo, D., Solidarity in the European Union in Times of Crisis: Towards "European Solidarity"?, in Federico, V.; Lahusen, C. (eds.), Solidarity as a Public Virtue? Law and Public Policies in the European Union, 2018, 195-249, pp. 201. 
since the beginning of the pandemic. That help is reflected in necessary medicines, medical equipment, various financial assistance mechanisms that will be further elaborated in the following chapters.

Bearing in mind the above mentioned aspects of the EU available mechanisms for combating the immediate consequences of the health and socio economic crises, the authors argue that the approach of the European Union towards its closest neighbours indicates the importance of the principle of solidarity, and that even facing the severe crisis itself, the European Union showed that it does not leave the Western Balkans behind. This was not taken for granted by the Montenegrin citizens, and the recent polls have shown a significant increase in the support towards Montenegrin membership to the EU - that has once again proven to be a major partner for the Western Balkans countries that they can always rely on.

\section{THE CONCEPT OF SOLIDARITY}

In order to consider solidarity in a legal and political sense, we must first point out its moral and human character. In this vein, cooperation with others has been the main precondition to survival and development from the very beginning of humanity. In that regard, things have not changed much up until today, as each association, organization or group, must contain a seed of solidarity in order to survive. Otherwise, sooner or later it won't exist. Thus, solidarity did not emerge as a legal principle as "by its origin and nature, solidarity is a moral principle and a universal human value"2. Keith Banting and Will Kymlicka maintain that solidarity among members of a political community is a precondition to the realization of human rights, to the functioning of "just institutions", as well as to the existence of a "just society - one that seeks to protect the vulnerable, ensure equal opportunities and mitigate undeserved inequalities". ${ }^{3}$

Cooperation between people implies mutual compromises, and solidarity as the basis of such a relation. ${ }^{4}$ Although at first glance it might seem that solidarity is the good will shown by those who are stronger and richer, practice challenges this belief and offers different proofs. This is particularly relevant in the crises such as

2 Lukić Radović, M., Solidarnost u pravu Evropske unije- uloga i perspektive, Pravni fakultet Univerziteta u Beogradu, 2018, p. 13.

3 Hostovsky Brandes, T., Solidarity as a Constitutional Value, Buffalo Human Rights Law Review, August 29, 2020, [http://dx.doi.org/10.2139/ssrn.3682992], p. 4.

4 Saraceno, F.; Fitoussi, J., Inequality, Growth, and Regional Disparities. Rethinking European Priorities, in Altomonte, C.: Villafranca, A. (eds.), Europe in Identity Crisis. The Future of the EU in the Age of Nationalism, 2019, 70-93, pp. 73. 
the one that we are currently facing due to Covid-19, which sets clear rules of the game - "nobody wins this race until everyone wins".

The concept of EU solidarity was evoked as "a guiding idea by the inspired political leaders who forged the very idea of a united Europe". ${ }^{5}$ Solidarity as a key value in the EU founding treaties is mentioned both as a general principle and as a norm which stipulates obligation on mutual support among member states and peoples during specific circumstances such as natural or man-made calamities. ${ }^{6}$ Habermas perceives solidarity ${ }^{7}$ as the very foundation for which concrete duties can be derived. Esin Küçük also argues that solidarity is to be defined as a legal principle that can have "binding legal implications" and therefore "normative effect". ${ }^{8}$

The duties upon Member states are likely to change over time and place, for instance, the COVID-19 pandemic gave birth to an entirely new set of duties upon individuals, such as the duty to maintain social distance and the duty to wear masks. The concept of solidarity could be perceived also as a litmus paper showing the richness of life over the norms, but also a proof of how well-prescribed norms, that in a way embrace the vividity of life, can positively affect a wide range of life aspects. The question is whether the European Union's responses to the crises would have been of similar quality and what implications they might have had in case there was no principle of solidarity? The principle of solidarity, in fact, was a key basis and essence of numerous decisions that rescued both some Member States and the sole EU as a supranational community in these challenging times awaking nationalistic behaviours and tensions all over the EU.

What distinguishes the Covid-19 crisis, is the fact that it does not present a threat for the national economies alone. In fact, due to its nature and scope it provided a strong impulse for the joint action. In case of the previous crises that hit the Union, "political and legal debates were basically structured around the idea of national responsibility", while in the situation of the Covid-19 pandemic "the structuring role is now claimed by the principle of solidarity" ". The European Union over years has created a solid legal basis for solving the crises which essence is embodied precisely in the principle of solidarity. It is now up to political elites leading the countries within

Di Napoli; Russo, op. cit., note 1, p. 211.

Ibid.

Habermas, J., The Postnational Constellation, Wiley Kindle Edition, Oxford, 1998, 1406.

$8 \quad$ Kucuk, E., Solidarity in EU Law: An Elusive Political Statement or a Legal Principle with Substance?, Maastricht Journal of European and Comparative Law, Vol. 23, No. 6, 2016, 965-983, pp. 975.

9 Ioannidis, M., Between Responsibility and Solidarity: COVID-19 and the Future of the European Economic Order, Max Planck Institute for Comparative Public Law \& International Law (MPIL) Research Paper Vol. 4, No. 80, Heidelberg Journal of International Law/Zeitschrift für ausländisches öffentliches Recht und Völkerrecht, 2020, p. 1-11. 
this supranational entity and leading the sole EU to make the best use of these instruments and existing possibilities and to combat the challenges that lie ahead.

\section{THE EU SOLIDARITY CLAUSE}

Solidarity has been one of the fundamental values since the inception of the EU integration project. Over years, solidarity went through a metamorphosis and along the way became a crucial value to be supported by the EU as a supranational entity that also aspires to play a more significant role at the international scene. There are quite a few arguments that support this thesis. The first one is related to the development of a common market. In other words, solidarity has played a major role in "mitigating the potentially divisive effects of the common market, and its associated freedom of movement of persons, goods, services and capital"10. Secondly, it was a key factor in the establishment of European integration as a stepwise process that has been built on an ad hoc established system of norms and mutual obligations. Solidarity was a key prerequisite for the long term success among all the participants involved. And thirdly, in times of crisis solidarity proved to be the key cohesive factor predetermining the success of such a valuebased community in managing the crises.

The solidarity clause of the EU stipulated by Article 122 TFEU assumed a central role during the COVID-19 crisis, clearly indicating the re-balancing between national responsibility and Union solidarity from what was the case during the Eurozone crisis. At the time Article 122 TFEU was a sideliner, "superseded by the new principle expressed in Article 136(1) TFEU- setting out the rule that assistance could only be possible under strict conditionality" ${ }^{11}$. Corona-times brought different status for the Article 122 TFEU, which served as the legal basis for many programmes, among others, Support to mitigate Unemployment Risks in an Emergency (hereinafter: SURE) and the NextGenerationEU. President of the Commission, Ursula von der Leyen, during the Eurogroup statement of 9 April 2020 called SURE "real European solidarity in action". ${ }^{12}$ Article 122 TFEU in the context of the NextGenerationEU, serves as the legal basis of its basic component which allows for targeted derogations from standard budget and financing of the Union rules in exceptional crisis situations. ${ }^{13}$

\footnotetext{
10 Di Napoli; Russo, op. cit., note 1, p. 202.

11 Case C-370/12, Pringle, para. 116.

12 Ursula von der Leyen, This is how the EU's $€ 100$ billion corona-fund will work, Euractiv, [https://www. euractiv.com/section/economy-jobs/news/this-is-how-the-eus-e100-billion-corona-fund-will-work/], Accessed 11 March 2021.

13 Ioannidis, op. cit., note 10, p. 5-6.
} 
The Union budget spending must be rational. By spending rationally, the EU is able to spend in a solidar manner, and that's the way on how funds can be determined for those in need. In line with that Armin von Bogdany and Justyina Lacny states that "the CJEU holds that the principle of sound financial management (applied in the area of EU funds) corresponds to the principle of sincere cooperation (as applied more generally in EU law)."14

Solidarity in access to health and medicines has been recognized as a cornerstone value to be guaranteed in EU policy and law. Another important document is the Patient's Rights Directive that was adopted in 2006, ${ }^{15}$ which stipulates that solidarity through universal access should be adhered to by the Union and in the Member States. Still, these provisions do not have the status of the primary law in the EU, although they do represent a European baseline for health law that is common to the Member States. ${ }^{16}$

One of the recent decisions brought by the General Court in the case of the Republic of Poland $v s$ European Commission annulling the European Commission's decision ${ }^{17}$ indicates the fact that this issue of the legal nature of the principle of solidarity is highly complex and important for the EU. The General Court upheld Poland's plea, by recognizing the binding nature of the principle of energy solidarity, which imposes a general obligation on both the EU and the Member States to take into account each other's interests and avoid measures that can affect the energy security interests of the other stakeholders. ${ }^{18}$

This judgment is not only limited to energy solidarity, but it declares that solidarity must always be taken into account. Confirmation of this judgment by the Court of Justice as the second instance would be of great importance for the whole Union, not only in the energy sector but in all other fields where solidarity is applied. By confirming the normative power of the principle of solidarity, decision-

$14 \quad$ Von Bogdandy A.; Lacny J., Suspension of EU Funds for Member States Breaching the Rule of Law - A Dose of Tough Love Needed, Swedish Institute for European Policy Studies, pp. 7.

15 Directive 2011/24/EU, 'Directive 2011/24/EU of the European Parliament and of the Council of 9 March 2011 on the Application of Patients' Rights in Cross-Border Healthcare (O.J. L88/45, 4-42011).

16 De Ruijter, A.; Beetsma, R.; et al, EU Solidarity and Policy in Fighting Infectious Diseases: State of Play, Obstacles, Citizen Preferences and Ways Forward, Amsterdam Centre for European Studies Research Paper No. 06, Amsterdam Law School Research Paper No. 17, 2020, pp. 6.

17 The principle of solidarity and the geopolitics of energy: Poland v. Commission (OPAL pipeline), p. 890, [https://curia.europa.eu/juris/document/document.jsf;jessionid=6A868C3F9717BC39B5EA554FD5FE520D? text $=\&$ docid $=217543 \&$ pageIndex $=0 \&$ doclang $=E N \&$ mode $=$ req $\&$ dir $=\& o c c=-$ first\&part=1\&cid=109512], Accessed 07 March 2021.

18 The principle of solidarity and the geopolitics of energy: Poland v. Commission (OPAL pipeline), p. 898. 
makers would have an undoubtful basis for providing assistance, as well as the legal obligation to act in this manner.

\section{DIFFERENTIA SPECIFICA OF THE COVID-19 SOLIDARITY TRIGGER AND THE EU ABSTENTION FROM THE "CONDITIONALITY TACTIC"}

The Covid-19 pandemic in comparison to the previous crises is a hazard that provoked substantially different reactions from the side of the EU, while solidarity became an omnipresent concept and basis of the EU strategy and instruments designed for combating the pandemic. According to Herman Van Rompuy this crisis has awakened "a kind of togetherness between people, grown out of the feeling that we are all in the same boat" ${ }^{\prime 1}$. In this endeavour of combating the negative consequences of the crisis an important move was disassociating the existing COVID-19 EU mechanisms from the legacy of conditionality - being important subtract present in the previous responses to the crises.

Conditionality as an EU policy tool has been applied since the late 1980s in the EU's external relations, more precisely, in the field of humanitarian aid to third countries. The rationale behind this approach is that states are "prompted to comply with requirements established under EU law in return for certain advantages". The same strategy has been applied in the process of establishment of the European Monetary Union in which the access of the less developed EU members to the Cohesion Fund was conditioned upon their compliance with the EU budget deficit rules. ${ }^{20}$

The reason for such different EU reactions in the environment of the Covid-19 pandemic lies in its character, the fate-like nature, and in the fact that this crisis was not the result of "fiscal profligacy, corruption, or broken institutions". In other words, there is no "national responsibility" argument as it was in the case with the Eurozone crisis. Here, as some authors imply "the moral hazard argument had a much clearer basis and stronger political clout". ${ }^{21}$ Therefore, the shock caused by the Covid-19 "made audiences and decision-makers across Europe much more receptive to arguments framed in terms of solidarity", which had recently shaped the historic responses from the side of the EU. ${ }^{22}$

\footnotetext{
19 Herman Van Rompuy, COVID-19: A turning point for the EU?, Discussion paper, European politics and institutions programme, 16 April 2020, p. 1.

20 Von Bogdandy; Lacny, op. cit., note 15, p. 5.

21 Ioannidis, op. cit., note 10, p. 3.

22 Ibid.
} 
There are plenty of examples of such a "conditionality free" EU approach, and some of them are Eurogroup agreement on the strategy to combat the crisis brought on 9 April 2020, and the European Stability Mechanism (ESM), the role of which is envisaged through its Pandemic Crisis Support component- "a virtually conditionality-free credit line available to euro area countries through a very expedient procedure". Support to mitigate Unemployment Risks in an Emergency (SURE) is another instrument introduced to provide favourable loans to the EU Member States in order to support their short-time working schemes.

Another historic decision was brought in May 2020, with a Franco-German compromise that led to the 'NextGenerationEU' recovery instrument. ${ }^{23}$ The European Council for the first time agreed to the basic contours of the programme that essentially mirrors the possibility of collective borrowing for the purpose of financing the expenditures, as part of EU's 2021-2027 multiannual financial framework (MFF). ${ }^{24}$ The NextGenerationEU instrument sets certain conditions that countries need to fulfil in order to receive the financial support under its main component called the Recovery and Resilience Facility (RRF) ${ }^{25}$ Their key obligation is to submit to the Commission national Recovery and Resilience Plans (RRPs) that need to be aligned with the Union standards. According to Pisani-Ferry, "this arrangement is (yet) neither typical conditionality ('first reform your pensions, then we can talk') nor rubber-stamping ('here's the money, please tell us what you do with it')" ${ }^{26}$

The special value of this approach reflects the sole nature of the available mechanisms as "intrusive rules of Regulation 472/2013 have been deactivated" 27 . This is particularly important, as if the solidarity mechanisms are tight with strict conditions, then conditional transfers present not an expression of solidarity but rather a surrogate of bureaucratic control. The age of Covid-19 is marked by the reduc-

23 Darvas, Z., "The nonsense of Next Generation EU net balance calculations', Policy Contribution, No. 03, Bruegel, 2021, 15.

The total maximum financial envelope of NGEU comprises grants and guarantees amounting to $€ 420$ billion, and loans amounting to $€ 375$ billion. These amounts will be disbursed via the seven facilities of NGEU: the Recovery and Resilience Facility (RRF, €312.5 billion in grants and $€ 360$ billion in loans); Recovery Assistance for Cohesion and the Territories of Europe (REACT-EU, €47.5 billion in grants); the Just Transition Funds (JTF, €10 billion in grants); Rural Development (€7.5 billion in grants); Horizon Europe ( $€ 5$ billion in grants), civil protection (RescEU, $€ 1.9$ billion in grants); and InvestEU (€5.6 billion of guarantees).

24 Ioannidis, op. cit., note 10, p. 2. It allows the EU to borrow 750 billion EUR in order to finance 390 billion EUR in non-repayable financial support (grants) and 360 billion EUR in loans for the EU member states.

25 Toniolo, G., Next Generation EU: Una condizionalità virtuosa, Luiss School of European Political Economy, Policy Brief, No. 33, 2020, p. 2.

26 Ioannidis, op. cit., note 10, p. 5.

27 Regulation 472/2013. 
tion of conditionality in this regard although it did not get everywhere the same sympathy. ${ }^{28}$

No matter how generous the help seems to be, we must not confuse solidarity with the gift. First of all, quality control mechanisms must be established for the purpose of transparency over the spending of funds. In addition, solidarity goes hand in hand with reciprocity - implying that states want to rely on the premise of equal treatment shown by the other actors involved, if they find themselves in a similar situation. In other words, as Peter Hilpold mentioned "solidarity expects solidarity." ${ }^{29}$ In regards to solidarity, there is always at least a small share of personal interest and therefore "solidarity has to be conceptually separated from altruism that is based on selflessness, while solidarity is always partly driven by self-interest." ${ }^{30}$ Esin Kucuk states, "the pursuit of self-interest, however, is not necessarily the reverse of solidarity, in fact, self-interest is the only driver of solidarity in the absence of altruistic or moral underpinnings." ${ }^{11}$ The fact that during the Covid-19 we are all on the same boat perfectly fits with the rationale explained, as due to the nature of this hazard no one will be safe until everyone is safe.

As Yuval Noah Harari ${ }^{32}$ rightly pointed out, in such a state of play, global cooperation isn't altruism. In fact, it becomes essential for ensuring the national interest.

\section{5. “NEED FOR SPEED”. A COVID-19 (QUEST FOR A SPEED ADAPTATION AND REACTION)}

A system 's responses to crises are changing according to the needs imposed by circumstances. Sometimes the circumstances are so grave that they render the existing mechanisms/responses useless almost overnight. Some systems are able to provide a quicker response and to adapt more swiftly, while some others due to highly complex internal structures of decision making are in a way slower, and this vacuum between the outbreak of the hazard and system 's response - can become a strong weapon in the hands of the opponents. That can result in the growth of

28 Giuseppe Conte, during the July 2020 summit, and Heiko Maas, Olaf Scholz in their article entitled "A response to the corona crisis in Europe based on solidarity", made a strong point for saying no to "unnecessary conditions". On the other hand, Finland case could depict the alternative approach to this matter.

29 Hilpold, P., Understanding Solidarity within EU Law: An Analysis of the 'Islands of Solidarity' with Particular Regard to Monetary Union, Yearbook of European Law, No. 34. 257-285, 2015, pp. 262.

30 Bouza da Costa, op. cit., note 7, p. 9.

31 Kucuk, op. cit., note 9, p. 967.

32 Harari, Y., Lessons from a year of Covid, 26 February 2021, [https://www.ft.com/content/f1b30f2c84aa-4595-84f2-7816796d684], Accessed 01 March 2021. 
the opponents 'relative power of questioning the credibility and reliability of these systems in general.

The SARS pandemic, for example, was one of the stepping stone moments that have brought new international rules, which led to revising the International Health Regulation that was approved during the 58th World Health Assembly, and since then, it has become the core instrument for regulating disease outbreaks with an international dimension. ${ }^{33}$

Covid-19 pandemic due to its character and outreach certainly provided another great impulse for such ground-breaking moves and could become a milestone in international relations and the functioning of international organizations. Nonetheless, not the WHO nor the EU were able to provide an instant and adequate response to such a hazard embodied in the Covid-19. On the contrary, the WHO went under great criticism that was primarily related to the inability to timely recognize the seriousness of the pandemic after its outbreak in China, slow response, politicization within the organization especially reflected in the behaviour of the major players within the WHO.

Although the EU's response at the beginning of the pandemic was not at a satisfactory pace, especially not for countries most severely hit, at the later stages of the pandemic, the EU managed to act in a consolidated way and to play a pivotal role in the continent and wider. Here we are especially referring to the generous assistance that the EU provided to its closest neighbours. One of the lessons learned is certainly that speed also matters. In this regard, better legal regulation of the principle of solidarity, would greatly help the Union to react faster and better, having a clear legal basis for doing so.

\section{THE EU ROLE IN ORGANIZING SOLIDARITY FOR HEALTH. RESOURCE ALLOCATION AND RATIONALIZATION OF PUBLIC GOODS}

Since the 1970s, with the development and use of European (disease) networks, the EU as a supranational entity has assumed powers in the field of surveillance and early warning of public health threats. Although "all this did not carve out a strong role for the EU in organizing solidarity for health, involving redistribution

33 Von Bogdandy, A.; Villarreal, P., International Law on Pandemic Response: A First Stocktaking in Light of the Coronavirus Crisis, Max Planck Institute for Comparative Public Law \& International Law (MPIL) Research Paper No. 07, 2020, p. 6. 
or rationing", it certainly influenced the creation of some mechanisms aiming at creating more efficient "health" responses at the EU level in times of crises. ${ }^{34}$

There are large differences among the EU Member states health systems, that can be distinguished by the quality of the health care, available resources, culture, organization, etc. ${ }^{35}$ This state of play strongly advocates in favour of cherishing the Member States' prerogatives in this field and the application of the so-called subsidiarity principle "as deviations from this principle could carry a danger of major inefficiencies or exacerbate inequalities" around Europe and have potentially detrimental effects on the Member States' healthcare systems.

On the other hand, in the case of infectious diseases such as Covid-19, the situation is quite the opposite from what has been previously said. Namely, decisions that aim to tackle spread of such diseases may have large cross-border spillovers, and the precedence of the 'national prerogatives', especially if the decisions are populist/inward oriented "may create a problem of collective action that could yield, in the end, bad outcomes for everyone."36

Nonetheless, imagining the EU as the key actor in this field requires trustworthiness "that it can also support the Member States in a tangible way, and that this supranational entity is capable of setting up real cooperation in order to keep citizens safer" ${ }^{37}$. Therefore, this explains why the recently adopted initiatives such as Joint Procurement initiative and the "rescEU" are so important. The first one, within the EU health regime, is able to ensure the size and volume of necessary procurement of medicines and medical equipment, while the second one creates a central allocation authority for the European Commission. ${ }^{38}$

Moreover, free movement and the integrity of the Single Market is another vehicle for strengthening the EU role in managing the crisis. In this vein, the Commission Communication has recently announced the free movement of goods as one of the instruments for coordinating Member States' actions, this is particularly important in the case of medicines and medical equipment due to their central

\footnotetext{
34 De Ruijter; Beetsma, et al., op. cit., note 17 , p. 8.

35 Hackenbroich, J.; Shapiro, J.; Varma, T., Health sovereignty: How to build a resilient European response to pandemics, European Council on Foreign Relations, Policy brief, 2020, p. 10.

36 De Ruijter; Beetsma, R. et al., op. cit., note 17, p. 21.

37 Communication from the Commission, A Modern Budget for a Union that Protects, Empowers and Defends. The Multiannual Financial Framework for 2021-2027, Brussels,2.5.2018, COM(2018) 321 final.

38 De Ruijter; Beetsma, et al., op. cit., note 17, p. 21.
} 
importance in combating COVID-19 pandemic. $^{39}$ In the case, a member state breaches the obligations and hinders flow of goods that are deemed essential for fighting COVID-19 the Commission establishes a task force to respond to this. ${ }^{40}$

Recognizing the current moment the EU Commission made another important step and has adopted the temporary state aid framework from 19 March, the basic goal of which was to insure that national governments can act swiftly and know what state aid measures do not constitute prohibited measures in order to tackle exceptional occurrence caused by the COVID-19 outbreak. ${ }^{41}$ On 4 April and 8 May the Commission extended the scope of the Temporary Framework “42, and by the fourth amendment of 13 October 2020, the Commission prolonged the Temporary Framework until 30 June 2021. ${ }^{43}$

However, one particular aspect of the story should not be neglected. In times of crisis, people's major concern is safety, so politicians led by the wish to save for themselves political points for handling the health emergencies are often showing reluctance to transfer the redistributive power to the EU level. These lessons learned imply that national political elites rather opt for a "domestic-centred equilibrium" 44 and are, therefore, turning to isolationist politics, as they are at least looking from the short-term perspective, a way more profitable.

\subsection{EU Public procurement procedures: only voluntary, not mandatory}

The EU can play an important role for COVID-19 in organising health solidarity through a European Public Procurement process. Nevertheless, the previous health crises were not that bright examples of EU solidarity, showing how fragile was the EU countries` system of obtaining vaccines and medications, as well as their low level of purchasing power. The main reason for that was the system cre-

39 Communication from the Commission to the European Parliament, the European Council, the Council, the European Central Bank (March 13, 2020), the European Investment Bank and the Eurogroup, Coordinated economic response to the COVID-19 Outbreak, COM(2020) 112 final, Brussels, pp. 3.

40 De Ruijter; Beetsma, et al., op. cit., note 17, p.14.

41 From 12 March to 26 October 2020, the Commission had adopted 435 decisions on COVID-19 related State aid measures, i.e. support for coronavirus-related research and development (vaccines and medicines); support for the construction and upscaling of testing facilities; support for the production of vaccines and medicines; support in the form of wage subsidies for employees, liquidity support for businesses that does not exceed EUR 800,000, etc.

42 Busch, D., Is the European Union Going to Help Us Overcome the COVID-19 Crisis?, European Banking Institute Working Paper Series, No. 64, 2020, pp. 7-8.

43 Bouchagiar, A., State aid in the context of the COVID-19 outbreak, including the Temporary Framework 2020, Robert Schuman Centre for Advanced Studies Florence School of Regulation, EUI Working Paper RSC. No. 03, 2021, pp. 2.

44 Busch, op. cit., note 53, p. 21-22. 
ated in 2011 and 2013 that envisaged "the voluntary public procurement medical countermeasure in case of a health emergency, that is either declared and identified by the WHO or by the European Commission". ${ }^{45}$

In June 2014 the Joint Procurement Agreement entered into force. It applies to joint procurement of medicines, further implementing Article 5.6 This joint procurement refers to different sorts of medicines, among which "antivirals, treatments or vaccines, also, medical devices (infusion pumps, needles) and 'other services and goods' needed to mitigate or treat cross-border threats to health, such as laboratory tests, diagnostic tools, decontamination products, masks or personal protective equipment, eye protection and respirators, and ventilators". ${ }^{47}$ The JPA has been signed by 37 countries, "including all EU and EEA countries, the UK, and the Western Balkans". ${ }^{48}$ The key goal of this voluntary mechanism is to support "fair and equitable access to, and distribution of, pandemic influenza vaccines, antivirals and other treatments for the future", to achieve in that way the greater level of security of supply and more balanced prices for the countries involved.

One more important achievement for public health and serious cross-border threat preparedness is the signature of framework contracts for the production and supply of pandemic Influenza vaccines. ${ }^{49}$ Article 5 of the Decision 1082/2013/ $\mathrm{EU}$ on serious cross-border threats to health presents the legal basis of this joint mechanism. This mechanism sets the common rules for the practical organisation of joint procurement procedures for the purpose of obtaining the medical countermeasures for different categories of "cross-border health threats" 50 . The key aspects of this mechanism are threefold. The first one is the determination of the

45 Decision No 1082/2013/EU of the European Parliament and of the Council of 22 October 2013 on serious cross-border threats to health and repealing Decision No 2119/98/EC [2013] OJ L 293/1.

46 European Commission, Public health: Joint purchasing of vaccines and medicines becomes a reality in the EU, 10 April 2014, [https://ec.europa.eu/commission/presscorner/detail/en/IP_14_41 ], Accessed 10 February 2021.

47 De Ruijter; Beetsma, et al., op. cit., note 17, p. 11.

48 European Commission, Public health: Joint purchasing of vaccines and medicines becomes a reality in the EU, 10 April 2014, [https://ec.europa.eu/commission/presscorner/detail/en/IP_14_418], accessed: 10 February 2021.

49 European Commission, Preparedness and response planning, [https://ec.europa.eu/health/security/preparedness_response_en], Accessed 20 March 2021.

50 MEMO 28/03/2019, Framework contracts for pandemic influenza vaccines, "A serious, cross-border threat to health is a life-threatening or otherwise serious hazard to health from a biological, chemical, environmental or unknown origin. Such threats spread or entail a significant risk of spreading across the national borders of Member States, and may require coordination at EU level in order to ensure a high level of human health protection", [https://ec.europa.eu/health/sites/health/files/preparedness_ response/docs/ev_20190328_memo_en.pdf], Accessed 21 March 2021. 
practical arrangements governing the mechanism. The second aspect is focusing on the decision-making process determining the choice of the procedures. Lastly, the third aspects are related to setting criteria for the assessment of the tenders and the award of the contract. ${ }^{51}$

In the case of urgency, that is declared by the Commission and the Member States participating in the Joint Procurement Agreement Steering Committee, a Member State is allowed to request derogation from the generally applicable criteria on the allocation of the medical countermeasures and to therefore receive them at a faster rate than other participating states..$^{52}$ Member States can also donate medical countermeasures acquired under the joint procurement procedure. ${ }^{53}$ Each procedure sets its own conditions and distributive regulations. ${ }^{54}$

\subsection{The EU Civil Protection Mechanism and "rescEU". (De)centralized procurement}

The EU Civil protection mechanism was created in 2013, as a successor of the Civil Protection Mechanism that was set up back in 2001 under Euratom. It is based on Art. 196 TFEU, according to which the Union has both internal and external competences in the field of civil protection. As stipulated by the Article 6(f) of the TFEU, the EU in the field of civil protection, has limited competences that are of the supporting, coordinating, or supplementing nature to the respective competencies of the Member States. ${ }^{55}$

Nonetheless, the experience with different crises has shown that reliance on voluntary offers of mutual assistance, coordinated and facilitated by the Union Mechanism, does not ensure satisfactory results, which particularly applies to the situations in which a number of countries are simultaneously affected by the crises.

Therefore, from 2019, the EU Civil Protection Mechanism was further complemented by the creation of rescEU - the key goal of which is to contribute to centralizing the EU capacities. ${ }^{56} \mathrm{RescEU}$ is designed "to provide assistance in overwhelming situations where overall existing capacities at a national level and those

MEMO 28/03/2019, Ibid.

52 Art. 17(2) JPA.

53 Art. 31 JPA.

54 Art. 17 JPA.

55 Article 169: "The Union shall encourage cooperation between Member States in order to improve the effectiveness of systems for preventing and protecting against natural or man-made disasters".

56 Decision (EU) 2019/420 of the European Parliament and of the Council of 13 March 2019 amending Decision No 1313/2013/EU on a Union Civil Protection Mechanism (OJ L 77I , 20.3.2019, p. $1-15)$. 
precommitted by the Member States to the European Civil Protection Pool are not, in the circumstances, able to ensure an effective response to the various kinds of disasters" ${ }^{\prime 57}$. The key aspects of this endeavour are mirrored in the Article 12 of this Decision that "provides for the EU to use its internal funds, precommitted national funds and EU co-financed Member States capacities at the disposal of EU efforts, to respond to a major emergency" ${ }^{58}$. RescEU also envisages the possibility for joint procurement, existing in parallel to the Joint Procurement Agreement under the health infrastructure (Art. 20) with a more central role to be given to the Commission.

The actual capacity of rescEU is predetermined by the Member States' willingness to contribute to the EU internal funding in this regard. The Member states have recently shown to be generally more interested in the national level initiatives or actions through the JPA in the EU health context. There are quite a few factors that could fit in the above statement. The first one are the diverse realities of the purchasing powers of the Member States. Furthermore, the absence of the EU budget is also another unfavourable objective circumstance. Last but not the least, the inability of this intergovernmental and bureaucratic structure to generate the necessary speed that an urgent procurement process would need is yet another factor that acts as a delusion for those advocating for the more EU centralised approach in this field.

On the other hand, there are a number of advantages of having centralized procurement at the EU level. One of the key benefits is related to the ability of the EU to negotiate a better position with pharmaceutical companies, diminishing in that way their relative power over the relation between different member states and especially over certain member states that could try to negotiate a better price. The second aspect is directly related to solving inefficiency of stockpiles managed by the individual member states, by creating a common stockpile of medical countermeasures managed at the EU level. That would solve the issue of excess demand in some countries and excess supply in other countries. Lastly, the risk-sharing for the purpose of combating the pandemic consequences with the common stockpile is much more effective than in the case when each member is responsible for its own stock of medicines and equipment. The common stockpile is at the same time a larger stockpile with much greater firepower to target outbreaks of infectious diseases. ${ }^{59}$ This would require a larger role for the European Commission,

\footnotetext{
57 Decision (EU) 2019/420 of 20 March 2019 of the European Parliament and of the Council of 13 March 2019 amending Decision 1313/2013/EU on a Union Civil Protection Mechanism, Art. 12 replaced.

58 Ibid.

59 De Ruijter; Beetsma, et al., op. cit., note 17, p. 24.
} 
securing a more efficient response than the current structure is able to achieve because all contracting parties have to instantly agree on the deployment of medical counter-measures in accordance with urgency and need. ${ }^{60}$

After the COVID-19 outbreak, the Western Balkans have activated the Union Civil Protection Mechanism (UCPM) and have already started to receive assistance from it. Three Western Balkan countries, namely, Serbia, North Macedonia and Montenegro are participating States in the Mechanism, able to contribute but also to request support of rescEU.

\section{BETWEEN SOLIDARITY AND NATIONALISM, TRUST BUILDING AS A BRIDGE TOWARDS MORE SOLIDARITY}

The crisis, severe as the Covid-19 one, that brought many changes to everyday life is expected to have far-reaching social effects on globalization. In line with this statement, the UN Secretary General says that: "[w] ith the right actions, the COVID-19 pandemic can mark the beginning of a new type of global and societal cooperation." ${ }^{61}$ Many debates have been activated since the outbreak of the crisis, and one that seems pretty relevant in this context is about the path that the EU member states are going to choose, namely: greater reliance on international institutions or nationalism. The first one goes hand in hand with the tendency of empowering the supranational/international institutions to be able to act in a more efficient way in times of crisis and in general. The second one is a tendency towards nationalism and populism, which seems to be gaining momentum in recent years, and it is not something unexpected as crises tend to strengthen national sentiments, "with people falling back on their nation-state, which has the financial, organisational and emotional strengths that global institutions lack." ${ }^{2}$

The authors who claim that we are witnessing the second scenario are relying upon the argument of the absence of the notion of community and sense of identity/ belonging to the international level. In addition, the EU as one of the most integrated communities has been a subject of great criticism by the Member states for failing to deliver on its promise of solidarity that further creates a negative sentiment that at the same time "strengthens the sense of nationalism and gives

$60 \quad$ Ibid, p. 13-14.

61 UN news, UN launches COVID-19 plan that could 'defeat the virus and build a better world, 31 March 2020, [https://news.un.org/en/story/2020/03/1060702], Accessed 20 March 2021.

62 Rachman, G., Nationalism is a side effect of coronavirus, The pushback against globalisation will come from protectionists, national-security hawks and greens, Financial Times, [https://www.ft.com/content/644fd920-6cea-11ea-9bca-bf503995cd6f], Accessed 10 April 2021. 
a louder voice to protectionists and populists". ${ }^{63}$ It can be also argued that the politicians have partially contributed to this sense of feeling threatened. Although the enemy is invisible, the "war talks" nevertheless creates the spectre of an enemy. War is associated with the "other/otherness", and the atmosphere that has been created by different narratives has the tendency to create and build on ethnonationalist sentiment. ${ }^{64}$

Although it seems that the trend of relying on protective nationalism as a reaction to the pandemic prevails, we also witness a growing atmosphere of solidarity among nations. This thesis can be substantiated by a number of examples, embodied in isolated or structured actions that are aimed to support those in need.

Here we should mention the cooperation between the physicians and medical researchers around the globe that struggled to invent a vaccination for COVID-19. The support was provided by China, Britain, Germany, France, etc. which had sent doctors and offered a financial package and medical material to Italy and other countries severely affected by the crises at the beginning of the pandemic. The support was also provided by the EU to its closest neighbours, the Western Balkans countries. Those are all examples proving that cooperation is extremely necessary especially for highly affected and developing countries, which due to their limited financial and human capabilities or poor economies, are not able to cope with the deep and far reaching consequences of the crises alone. ${ }^{65}$ Although it seems to be overlooked thus far, this aspect that highlights the benefits of cooperation and solidarity is growingly important - implying that in the long term, there could be more tendency towards globalization and unification as the Covid-19 may not be the only situation placing as all on the same boat.

In order to move in that direction, trust-building between the participating states and the democratic scrutiny of "assistance" transfers are certainly important preconditions to developing a more consolidated and solidar approach in times of crises. The aspect of trust building is particularly important as the concept opposite to the system of control, which is able to generate the presumption of agreement with the EU's actions.

63 Yacoub, A.; El-Zomor, M., Would COVID-19 Be the Turning Point in History for the Globalization Era? The Short-Term and Long-Term Impact of COVID-19 on Globalization, 2020, pp. 12.

64 We don't need a 'war' against coronavirus. We need solidarity, [https://coronavirusnews.psmghana. com/index.php/2020/04/06/we-dont-need-a-war-against-coronavirus-we-need-solidarity/], Accessed 07 April 2021.

65 Yacoub; El-Zomor, op. cit., note 74, p. 10. 
Another aspect is the transfer of democratic scrutiny at a European level over the use of European funds by the Member States ${ }^{66}$ in order to establish transparency and effective monitoring on how national governments spend the funds. The decision to tie the NextGenerationEU to the European Semester and the insistence on rule-of-law conditionality are justified also from that, so-called solidarity-reinforcing perspective.

\section{SOLIDARITY IN ACTION. THE EU APPROACH TOWARDS ITS CLOSEST NEIGHBOURS.}

Since the beginning of the Covid-19 pandemic, although heavily affected by the pandemic, the EU has taken a proactive role towards its closest neighbours, and has included them in the strategies and various programmes aimed at tackling the health and socio-economic consequences of the crises. This approach once again explicitly showed that the EU leaves no one behind, especially not its partners in need, the Western Balkans.

As indicated in the Commission Communication on the "Support to the Western Balkans in tackling COVID-19 and the post-pandemic recovery" of 29 April $2020^{67}$ the total bilateral and regional EU assistance package for the Western Balkans in response to COVID-19 currently exceeds 3.3 billion EUR. The aim of this generous support that the EU has provided to the Western Balkans is to address the immediate health crisis and resulting humanitarian needs, as well as contribute to longer term and structural impact on their societies and economies.

More precisely, the mentioned support consists of various instruments, and those are as follows:

a) reallocations from the Instrument for Pre-accession Assistance amounting to 38 million EUR of immediate support for the health sector;

b) 389 million EUR to respond to social and economic recovery needs;

c) 455 million EUR economic reactivation package for the region in close cooperation with the International Financial Institutions;

${ }_{66}$ Wolff, Without good governance, the EU borrowing mechanism to boost the recovery could fail, [https:// www.bruegel.org/2020/09/without-good-governance-the-eu-borrowing- mechanism-to-boost-the-recovery-could-fail/], Accessed 03 February 2021.

${ }_{67}$ Communication from the Commission to the European Parliament, the Council, the European Economic and Social Committee and the Committee of the Regions Support to the Western Balkans in tackling COVID-19 and the post-pandemic recovery, Commission contribution ahead of the EU-Western Balkans leaders meeting on 6 May 2020, [https://ec.europa.eu/neighbourhood-enlargement/sites/near/files/com_2020_315_en.pdf], Brussels, 29.4.2020, COM(2020) 315 final. 
d) a proposal ${ }^{68}$ for EUR 750 million of Macro Financial Assistance

s) 1.7 billion EUR ${ }^{69}$ package of assistance from the European Investment Bank. ${ }^{70}$

Other than mentioned assistance, the EU also envisages help via the EU Solidarity Fund to the states that have started negotiation talks, support to the private sector in cooperation with International Financial Institutions, as well as the immediate humanitarian assistance to vulnerable refugees and migrants amounting to 4.5 million EUR and 8 million EUR of emergency support to migrants and refugees stranded in the Western Balkans from the Instrument contributing to Stability and Peace. ${ }^{71}$

The EC has also adopted a measure of 70 million EUR under the Instrument for Pre-Accession (IPA II) to help fund the access of Western Balkans to vaccines and necessary vaccination equipment procured by the EU Member States. In addition, the EU in cooperation with the World Health Organisation (WHO) has launched a new regional project amounting to over 7 million EUR aimed at supporting safe and effective vaccination of the people across the region. ${ }^{72}$

Besides the measures aimed at tackling the immediate consequences of the Covid-19 crisis, the EU has developed an Economic and Investment 2021-2027 plan for the region in which the Green transition and the Digital transformation will play a central role. The total envelope for the Pre-Accession Instrument III is 14.5 billion EUR. The Commission foresees a doubling in the provision of grants through the Western Balkans Investment Framework to support private sector development, connectivity, digitalisation, green agenda and social investments. ${ }^{73}$

Challenges faced by young people, in terms of job prospects, inequality and retaining young talent in the region to tackle the brain drain are also within the scope of EU attention. Via Erasmus+ programme it has doubled its funding since

68 2020/0065 (COD) Proposal for a Decision of the European Parliament and of the Council on providing MacroFinancial Assistance to enlargement and neighborhood partners in the context of the COVID-19 pandemic crisis. 22 April 2020.

69 Montenegro: EIB and IDF sign $€ 50$ million loan to support faster post-COVID recovery of SMEs and mid-caps, [https://www.eib.org/en/press/all/2020-238-eib-and-idf-sign-eur50-million-loan-tosupport-faster-post-covid-recovery-of-smes-and-mid-caps-in-montenegro], Accessed 08 April 2021.

70 Op. cit, $\operatorname{COM}(2020) 315$ final.

71 Ibid.

72 European Commission, New EU project to support readiness for vaccination efforts and resilient health systems in the Western Balkans, [https://ec.europa.eu/commission/presscorner/detail/en/ ip_21_683], Accessed 10 April 2021.

73 Ibid. 
2018 to over 65 million EUR to address the key challenges faced by youth and to better prepare them for the labour market.

These figures present essential and unparalleled support provided to the Western Balkans aimed at fostering the stability and prosperity of this region. They arose as a result of the so-called 'Team Europe' approach ${ }^{74}$ - that envisages quick and targeted support which entails resources pooled from the EU institutions, the Member States and financial institutions, in particular the European Investment Bank and the European Bank for Reconstruction and Development. In addition to this, Member States can also decide to provide assistance on a bilateral basis.

\section{THE EU SUPPORT TO MONTENEGRO}

Montenegro is one of the smallest European countries that declared outbreak of infectious coronavirus disease on 26 March 2020. Recently Montenegro has been facing alarming percentages in the number of infected people and unfortunately high mortality rate as well, in European, but also in the global context.

Additional aspect that should not be neglected is the low level of diversification of Montenegrin economy and high level of dependence on tourism (which share in Montenegrin GDP amounts to approximately 25 percent), that made Montenegro particularly fragile in terms of handling the economic and financial repercussions of the crisis. That has left deep consequences on the country, leading it to severe recession trends.

Recognizing these alarming circumstances, the European Union acted very quickly and from the start of the pandemic and have mobilised a substantial package of 53 million EUR of non-repayable financial aid and 60 million EUR of favourable loans as part of macro-financial assistance for Montenegro.

From the 3 million EUR for immediate responses (part of non-repayable financial aid), the EU has funded the delivery of a range of personal protection equipment, ventilators and $\mathrm{x}$-ray machines. The 40.5 million EUR Resilience Contract Budget Support is aimed to reduce the negative effects of the crisis on the economy, particularly focusing on protecting vulnerable social groups. Finally, the 9.5 million EUR Health programme will help to upgrade health infrastructure - build two new hospital wings in Podgorica and refurbish a dozen laboratories, and improve capacities to deal with future epidemiological threats. Additional hundreds

74 Communication on the Global EU response to COVID-19 (JOIN(2020)11 final) of 8.4.2020. 
of thousands of pieces of personal protective equipment have been donated by the EU Member States and the EU, through the Civil Protection Mechanism. ${ }^{75}$

Montenegro has also received 2.4 million EUR as part of the Pre-Accession (IPA II) package that will allow it to get the access to COVID-19 vaccines procured by the EU Member States. ${ }^{76}$ In addition, since October 2020, Montenegro has become a part of the COVAX initiative, which presents a global scheme that brings together governments and manufacturers to ensure eventual COVID-19 vaccines reach those in greatest need. Based on this agreement Montenegro will receive 248.800 doses of vaccines. Last month Montenegro received the delivery of 84,000 doses of the AstraZeneca vaccine. ${ }^{77}$

Furthermore, the European Commission has allocated around 200,000 EUR of additional support to Montenegro, in order to contribute to the fight against Covid-19. The donation is part of the package proposed by the European Commission of almost 530 million EUR in additional support under the EU Solidarity Fund to safeguard public health in fighting the coronavirus.

In cooperation with the Montenegrin Investment Development Fund and commercial banks, the EIB provided 100 million EUR in favourable loans to support tourism and other sectors severely affected by COVID-19 and help companies sustain liquidity and jobs.

Closer insight into the data about the assistance provided to Montenegro from the side of international institutions on one hand and the EU, on the other hand, leads us to the conclusion that the EU provided more aid to Montenegro than the World Bank and the MMF did jointly. In addition to financial assistance, as it has been described above, the EU has provided Montenegro with the necessary medical equipment, vaccines, etc.

This approach and care shown by the EU once again proved that this supranational entity is the most important and reliable international partner of Montenegro and that European integration is the only safe path that our country should take. Although the Union was criticised because of the speed of reaction at the

75 Delegation of the European Union to Montenegro, Signing a Financing Agreement on EU assistance to the health sector in the fight against Covid-19, [https://eeas.europa.eu/delegations/montenegro/92162/signing-financing-agreement-eu-assistance-health-sector-fight-against-covid-19_en], Accessed 05 April 2021.

76 European Commission, Commission adopts $€ 70$ million package for early access to EU COVID-19 vaccines in the Western Balkans, [https:/ec.europa.eu/commission/presscorner/detail/en/ ip_20_2539], Accessed 07 April 2021.

77 Ibid. 
beginning of the crisis, after the internal consolidation, it managed to react effectively and selflessly to help all countries involved. What made the position of the EU particularly difficult were the competencies the EU has in this area, in which Member states are actually playing the key role causing the slow response. Therefore, one of the key lessons learned from this process should be that the pandemic is not to be taken as an exceptional case, but the EU should rather get prepared for the future shocks it might face in order to be able to act efficiently in the manner of a credible international actor from the very beginning.

\section{CONCLUSION}

Solidarity constitutes the essence of the EU integration processes. From the very beginning of the idea on joint market and peaceful coexistence there is a present mantra of solidarity that is explicitly expressed through the Schuman declaration, that says: "Europe will not be made all at once, or according to a single plan. It will be built through concrete achievements which first create a de facto solidarity"78. Although it builds upon the existing international heritage, the UN General Assembly's resolutions from 2001 and $2002,{ }^{79}$ the idea of solidarity within the EU presents a bright example, as it went quite a few steps ahead - by the EU`s continuous work on growing the status and factual importance of the principle of solidarity.

The joint feature of all the crises that have recently hit the EU was that they required a great effort and solidarity from the side of the EU institutions and member states in both economic/financial and infrastructural terms. Despite its various forms (economic, financial, migrant, health crisis, etc.) these crises have heavily affected the Union, questioning its capacity to effectively address the issues, unleashing political tensions and discourse of nationalism within and among member states. At the same time these crises also taught us many important lectures, and one of the key implies that if we want a strong and resilient Union, solidarity must be cherished as a key principle by decision-makers and citizens, as a legal and moral obligation to help those in need, all for the sake of long term benefit of all.

Therefore, recognition of solidarity as a legal obligation would be an essential move that would help the EU to be able to act efficiently and timely address future crises. In this vein, the mentioned judgment of the European Court of Justice

\footnotetext{
78 Schuman. Robert, Declaration of 9th of May 1950, [https://www.robert-schuman.eu/en/doc/questions-d-europe/qe-204-en.pdf], Accessed 07 March 2021.

79 UN General Assembly, Promotion of a democratic and equitable international order: Resolution adopted by the General Assembly, 25 February 2003, A/RES/57/213, [https://www.refworld.org/docid/3f49d46a4.html], Accessed 10 March 2021.
} 
regarding Germany's appeal against the first-instance decision is eagerly awaited. If the Court confirms the first-instance judgment, that will give rise to a completely new Union, empowered with one important mechanism - able to save millions, both lives and euros.

Since one important aspect of solidarity is financial assistance, special attention must be devoted to establishing a transparent and continuous control over spending of the funds, accompanied with harsh penalties for those who commit violations. Only in this way, the misuse of funds can be prevented and thus the legitimacy of the generous assistance provided (to the countries in need) secured. The principle of control must be applied also in case of the aspiring member states, such as Montenegro in order to ensure that the funds allocated by the EU are spent for a specific designated purpose. This particularly applies to the funds intended for the construction of hospitals and the refurbishment of the existing ones. To what extent this is important indicates the fact that the last general hospital in Montenegro was built in 1946, the special hospital in 1953 and the Clinical Center of Montenegro in 1974. Proper investments in this health infrastructure is essential to creating better living conditions for all citizens, that in turn has a great potential of strengthening the public support/legitimacy of the European Union. Letting the citizens feel the firsthand benefits, and de facto solidarity means letting them feel the authenticity of the value based community such as the EU.

As the famous quote says "in the middle of difficulty lies opportunity" and the Covid-19 pandemic should also be viewed from a positive side. Turning out mirrors into windows in the context of Covid-19, would mean finding inspiration for cooperation and solidarity, so that 2020 "would not be a wasted year" but a serious milestone for the development of the EU/all mankind. It is up to all of us to contribute to the realization of positive predictions. Crisis such as the Covid-19 one could have a strong potential to act as katalizators bringing to the surface quality decisions and speeding up processes, so it's up to Member states and institutions to channel them in a proper direction. The Covid pandemic is a chance. This chance was given to us in order to understand the importance of mutual help and to develop new knowledge and skills. Just as the International Health Regulation was amended after the SARS pandemic, Covid-19 could provide for another great impulse to amend the existing EU and international agreements in order to secure better protection to the most vulnerable ones. Also, the crisis is a warning that if certain changes do not happen, there is a justified fear that other "fate-like" environmental and information crises, which are likely to happen in the future, could be even more detrimental. Let us only imagine what confusion and collapse would the Internet and other digital forms of international communication cause if they stop functioning, or what would be the consequences of increase 
in the greenhouse gas levels? Unfortunately, the level of consciousness about the seriousness of these threats is in general not high enough to allow us to predict their consequences, which can be more fatal to the economy and people than a Covid-19 pandemic.

Lastly, the Covid-19 crisis had taught us an indispensable lesson on how it feels to be on the same boat, or in other words, about our common fate. It has a strong potential of inspiring more cooperation and solidarity among nations. That is exactly what happened in the European continent. Although the speed of the EU reaction was criticised at the beginning of the pandemic, the EU managed to consolidate efforts and to take an active and notable role in managing the crisis on the continent and wider. The EU acting towards its closest neighbours and treating them as privileged partners in these uncertain times provides for additional proof that the European path is plausible and a firm path, and the only one that Montenegro and the Western Balkans should take.

\section{REFERENCES}

\section{BOOKS AND ARTICLES}

1. Van Rompuy, H., COVID-19: A turning point for the EU?, Discussion paper, European politics and institutions programme, 16 April 2020, p. 1-4

2. Darvas, Z., "The nonsense of Next Generation EU net balance calculations', Policy Contribution, No. 03, Bruegel, 2021, p. 1-16

3. Toniolo, G., Next Generation EU: Una condizionalità virtuosa, Luiss School of European Political Economy, Policy Brief, No. 33, 2020, p. 1-6

4. Hilpold, P., Understanding Solidarity within EU Law: An Analysis of the 'Islands of Solidarity' with Particular Regard to Monetary Union, Yearbook of European Law, No. 34. 257-285, 2015, pp. 262-285

5. Harari, Y., Lessons from a year of Covid, 26 February 2021, [https://www.ft.com/content/ f1b30f2c-84aa-4595-84f2-7816796d684], Accessed 01 March 2021

6. Von Bogdandy, A.; Villarreal, P., International Law on Pandemic Response: A First Stocktaking in Light of the Coronavirus Crisis, Max Planck Institute for Comparative Public Law \& International Law (MPIL) Research Paper No. 07, 2020, p. 6-10

7. Hackenbroich, J.; Shapiro, J.; Varma, T., Health sovereignty: How to build a resilient European response to pandemics, European Council on Foreign Relations, Policy brief, 2020, p. 10-19

8. Busch, D., Is the European Union Going to Help Us Overcome the COVID-19 Crisis?, European Banking Institute Working Paper Series, No. 64, 2020, pp. 7-8

9. Bouchagiar, A., State aid in the context of the COVID-19 outbreak, including the Temporary Framework 2020, Robert Schuman Centre for Advanced Studies Florence School of Regulation, EUI Working Paper RSC. No. 03, 2021, pp. 2-69 
10. Rachman, G., Nationalism is a side effect of coronavirus, The pushback against globalisation will come from protectionists, national-security hawks and greens, Financial Times, [https://www. ft.com/content/644fd920-6cea-11ea-9bca-bf503995cd6f], Accessed 10 April 2021.

11. Yacoub, A.; El-Zomor, M., Would COVID-19 Be the Turning Point in History for the Globalization Era? The Short-Term and Long-Term Impact of COVID-19 on Globalization, 2020, pp. $12-21$

12. Di Napoli, E.; Russo, D., Solidarity in the European Union in Times of Crisis: Towards "European Solidarity"?, in Federico, V.; Lahusen, C. (eds.), Solidarity as a Public Virtue? Law and Public Policies in the European Union, 2018, 195-249, pp. 201-235

13. Lukić Radović, M., Solidarnost u pravu Evropske unije-uloga i perspektive, Pravni fakultet Univerziteta u Beogradu, 2018

14. Hostovsky Brandes, T., Solidarity as a Constitutional Value, Buffalo Human Rights Law Review, August 29, 2020, [http://dx.doi.org/10.2139/ssrn.3682992], p. 1-31

15. Saraceno, F.; Fitoussi, J., Inequality, Growth, and Regional Disparities. Rethinking European Priorities, in Altomonte, C.: Villafranca, A. (eds.), Europe in Identity Crisis. The Future of the EU in the Age of Nationalism, 2019, pp. 70-93

16. Bouza da Costa, P., Conceptualisation of Solidarity in EU law, Leiden University, 2019

17. Habermas, J., The Postnational Constellation, Wiley Kindle Edition, Oxford, 1998

18. Kucuk, E., Solidarity in EU Law: An Elusive Political Statement or a Legal Principle with Substance?, Maastricht Journal of European and Comparative Law, Vol. 23, No. 6, 2016, 965-983

19. Ioannidis, M., Between Responsibility and Solidarity: COVID-19 and the Future of the European Economic Order, Max Planck Institute for Comparative Public Law \& International Law (MPIL) Research Paper Vol. 4, No. 80, Heidelberg Journal of International Law/Zeitschrift für ausländisches öffentliches Recht und Völkerrecht, 2020, p. 1-11

20. Von Bogdandy A.; Lacny J., Suspension of EU Funds for Member States Breaching the Rule of Law - A Dose of Tough Love Needed, Swedish Institute for European Policy Studies, pp. 1-15

21. De Ruijter, A.; Beetsma, R.; et al, EU Solidarity and Policy in Fighting Infectious Diseases: State of Play, Obstacles, Citizen Preferences and Ways Forward, Amsterdam Centre for European Studies Research Paper No. 06, Amsterdam Law School Research Paper No. 17, 2020, pp. 1-31

\section{COURT OF JUSTICE OF THE EUROPEAN UNION}

1. Poland v. Commission (OPAL pipeline)

2. Case C-370/12, Pringle, para. 116

\section{EU LAW}

1. 2020/0065 (COD) Proposal for a Decision of the European Parliament and of the Council on providing MacroFinancial Assistance to enlargement and neighborhood partners in the context of the COVID-19 pandemic, crisis, 22 April 2020 
2. Communication from the Commission to the European Parliament, the European Council, the Council, the European Central Bank (March 13, 2020), the European Investment Bank and the Eurogroup, Coordinated economic response to the COVID-19 Outbreak, $\operatorname{COM}(2020) 112$ final, Brussels

3. Communication from the Commission to the European Parliament, the Council, the European Economic and Social Committee and the Committee of the Regions Support to the Western Balkans in tackling COVID-19 and the post-pandemic recovery, Commission contribution ahead of the EU-Western Balkans leaders meeting on 6 May 202, [https:// ec.europa.eu/neighbourhood-enlargement/sites/near/files/com_2020_315_en.pdf], Brussels, 29.4.2020, $\operatorname{COM(2020)~} 315$ final

4. Communication on the Global EU response to COVID-19 (JOIN(2020)11 final) of 8.4.2020

5. Decision (EU) 2019/420 of 20 March 2019 of the European Parliament and of the Council of 13 March 2019 amending Decision 1313/2013/EU on a Union Civil Protection Mechanism, Art. 12 replaced

6. Decision (EU) 2019/420 of the European Parliament and of the Council of 13 March 2019 amending Decision No 1313/2013/EU on a Union Civil Protection Mechanism (OJ L 77I , 20.3.2019, p. 1-15)

7. Decision No 1082/2013/EU of the European Parliament and of the Council of 22 October 2013 on serious cross-border threats to health and repealing Decision No 2119/98/EC [2013] OJ L 293/1

8. Directive 2011/24/EU, 'Directive 2011/24/EU of the European Parliament and of the Council of 9 March 2011 on the Application of Patients' Rights in Cross-Border Healthcare (O.J. L88/45, 4-4-2011)

9. European Commission, Preparedness and response planning, [https://ec.europa.eu/health/ security/preparedness_response_en], Accessed 20 March 2021

10. Joint Procurement Agreement to procure Medical Countermeasures, Art. 17(2), 31, 17, [https://ec.europa.eu/health/sites/health/files/preparedness_response/docs/jpa_agreement_ medicalcountermeasures_en.pd], Accessed 21 March 2021

11. MEMO 28/03/2019, Framework contracts for pandemic influenza vaccines, [https:// ec.europa.eu/health/sites/health/files/preparedness_response/docs/ev_20190328_memo_ en.pdf], Accessed 21 March 2021

12. Schuman, Robert, Declaration of 9th of May 1950, [https://www.robert-schuman.eu/en/ doc/questions-d-europe/qe-204-en.pdf], Accessed 07 March 2021

13. Treaty of Lisbon amending the Treaty on European Union and the Treaty establishing the European Community [2007] OJ C306/01

\section{WEBSITE REFERENCES}

1. Delegation of the European Union to Montenegro, Signing a Financing Agreement on EU assistance to the health sector in the fight against Covid-19, [https://eeas.europa.eu/delegations/montenegro/92162/signing-financing-agreement-eu-assistance-health-sector-fightagainst-covid-19_en], Accessed 05 April 2021 
2. European Commission, Commission adopts $€ 70$ million package for early access to EU COVID-19 vaccines in the Western Balkans, [https://ec.europa.eu/commission/presscorner/detail/en/ip_20_2539], Accessed 07 April 2021

3. European Commission, New EU project to support readiness for vaccination efforts and resilient health systems in the Western Balkans, [https://ec.europa.eu/commission/presscorner/detail/en/ip_21_683], Accessed 10 April 2021

4. European Commission, Public health: Joint purchasing of vaccines and medicines becomes a reality in the EU, 10 April 2014, [https://ec.europa.eu/commission/presscorner/detail/en/ IP_14_418], Accessed 10 February 2021

5. Montenegro: EIB and IDF sign $€ 50$ million loan to support faster post-COVID recovery of SMEs and mid-caps, [https://www.eib.org/en/press/all/2020-238-eib-and-idf-sign-eur50million-loan-to-support-faster-post-covid-recovery-of-smes-and-mid-caps-in-montenegro], Accessed 08 April 2021

6. The principle of solidarity and the geopolitics of energy: Poland v. Commission (OPAL pipeline), p. 890, [https://curia.europa.eu/juris/document/document.jsf;jsessionid=6A868 C3F9717BC39B5EA554FD5FE520D? text $=\&$ docid $=217543 \&$ pageIndex $=0 \&$ doclang $=\mathrm{E}$ N\&mode=req\&dir=\&occ=first\&part=1\&cid=109512], Accessed 07 March 2021

7. UN General Assembly, Promotion of a democratic and equitable international order : Resolution adopted by the General Assembly, 25 February 2003, A/RES/57/213, [https:/www. refworld.org/docid/3f49d46a4.html], Accessed 10 March 2021

8. UN news, UN launches COVID-19 plan that could 'defeat the virus and build a better world', 31 March 2020, [https://news.un.org/en/story/2020/03/1060702], Accessed 20 March 2021

9. Ursula von der Leyen, This is how the EU's $€ 100$ billion corona-fund will work, Euractiv, [https://www.euractiv.com/section/economy-jobs/news/this-is-how-the-eus-e100-billioncorona-fund-will-work/], aAccessed 11 March 2021

10. We don't need a 'war' against coronavirus. We need solidarity, [https://coronavirusnews. psmghana.com/index.php/2020/04/06/we-dont-need-a-war-against-coronavirus-we-needsolidarity/], Accessed 07 April 2021

11. Wolff, Without good governance, the EU borrowing mechanism to boost the recovery could fail, [https://www.bruegel.org/2020/09/without-good-governance-the-eu-borrowing-mechanism-to-boost-the-recovery-could-fail/], Accessed 03 February 2021 